\title{
RADIOCARBON DATING RECENT VOLCANIC ACTIVITY ON FAIAL ISLAND (AZORES)
}

\author{
JOSÉ MADEIRA, ${ }^{1}$ A. M. MONGE SOARES, ${ }^{2}$ ANTONIO BRUM DA SILVEIRA ${ }^{1}$ and \\ ANTONIO SERRALHEIRO ${ }^{1}$
}

\begin{abstract}
Recent fieldwork on the island of Faial (Azores) led to the establishment of a detailed volcanic stratigraphic sequence, which is composed of five main geological formations. One of them, the Caldeira Formation, comprising mainly pumice fall and flow deposits, was judged to be Holocene in age. Organic materials were found preserved in or below some of the pyroclastic deposits from this formation. Wood, charcoal, peat and soil samples were radiocarbon dated, permitting correlation of deposits from different sequences and the establishment of a chronological framework for the Caldeira volcanic activity. These materials yielded ages from ca. 10-1 ka BP. The average dormant interval in the Caldeira pyroclastic activity from 4-1 ka ago is ca. $400 \mathrm{yr}$, with eruptions approximately every $200-800 \mathrm{yr}$. This frequency of activity indicates that the Caldeira volcano is an active, dangerous structure that should be closely monitored.
\end{abstract}

\section{INTRODUCTION}

The Azores archipelago is located in the area where the North American, Eurasian and African lithosphere plates meet (Fig. 1). The high seismic and volcanic activity of these islands is due to their tectonic location. Since 1439, 30 eruptive events have been recorded in the Azores, i.e., a volcanic episode every $18 \mathrm{yr}$, on average.

Recent fieldwork on Faial led to the establishment of a volcanic stratigraphic sequence in which five main geological formations were recognized (Serralheiro et al. 1989): 1) Ribeirinha Complex (800$580 \mathrm{ka} \mathrm{BP}$ - mainly hawaiitic lava flows of a former shield volcano, partially destroyed;2) Cedros Complex (470-10 ka BP)-basaltic to benmoreitic lava flows, scoria cones and trachytic domes from the central volcano; 3) Almoxarife Formation (50-10 ka BP)-basaltic scoria cones and lava flows from the fissural volcanic activity in the eastern part of the island; 4) Caldeira Formation (Holocene age)-trachyte pumice fall deposits, phreatic and phreatomagmatic breccias, surges, ignimbrites and lahars related to the formation of a summit caldera on the central volcano; 5) Capelo Complex (?-present)-basaltic scoria cones and lava flows from fissural volcanic activity in the western part of the island; two historic eruptions (1672-1673 and 1957-1958) were recorded.

One of the goals of our research on Faial was to establish a chronological framework for the Caldeira Formation. Several stratigraphic sequences were identified, but their relations in time and space were unclear. We ${ }^{14} \mathrm{C}$-dated 19 samples of organic remains, such as roots, trunks or branches of trees, charcoal fragments and humic acids extracted from paleosols, which were preserved by some of the pyroclastic deposits, to correlate these sequences. The data obtained also allow us to determine the average dormant interval between the Caldeira explosive events and, consequently, the degree of hazardousness of this structure. Three samples of charcoal from other deposits not directly related to the Caldeira Formation were also dated.

\section{METHODS}

We used four kinds of samples in this work: wood, charcoal, peat and soil. Sampling locations and schematic geologic sections of the localities from which samples were collected are shown in Figure 2. As one of the primary objectives of this study was to determine the age of volcanic events, we

\footnotetext{
${ }^{1}$ Departamento de Geologia, Faculdade de Ciências, Universidade de Lisboa, 1700 Lisboa, Portugal

${ }^{2}$ Laboratório de Isótopos Ambientais, Departamento de Química, ICEN/INETI, 2685 Sacavém, Portugal
} 


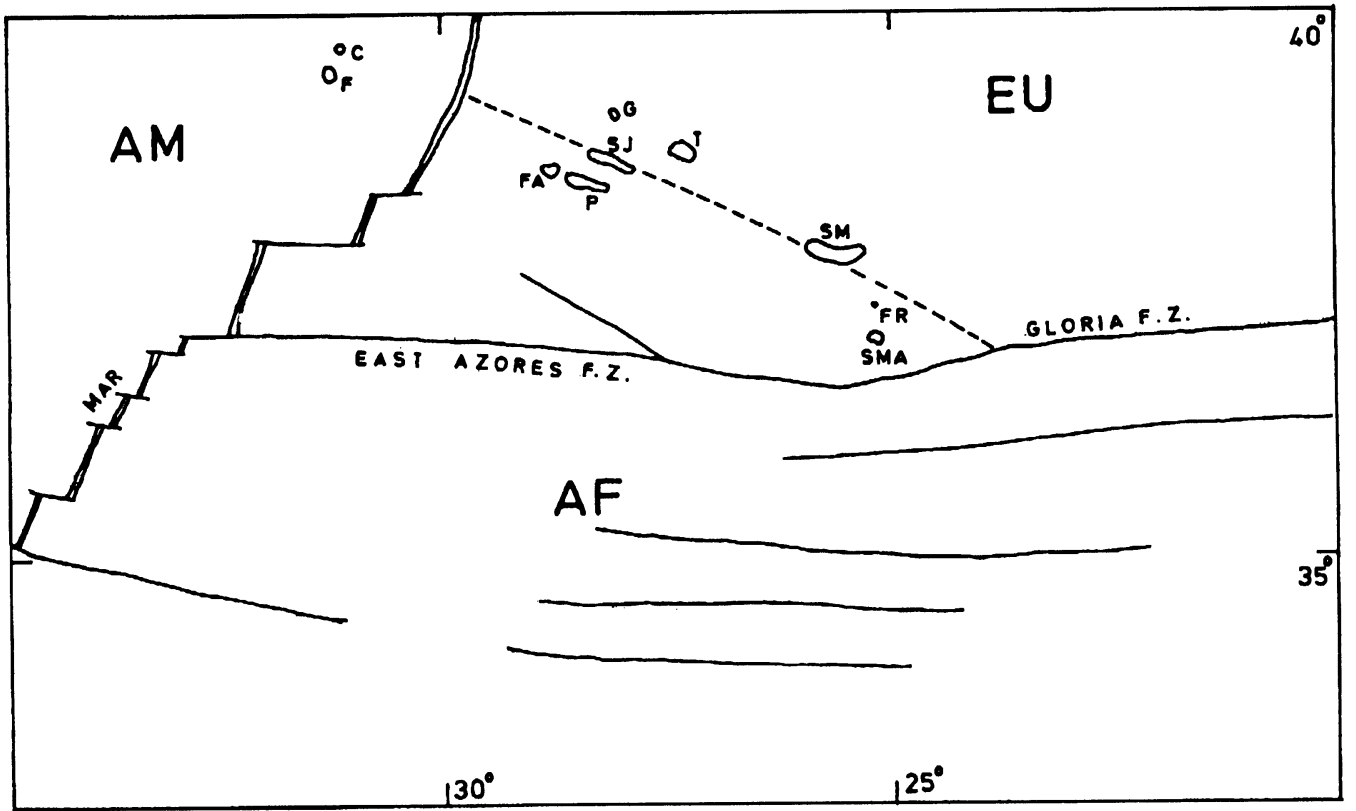

Fig. 1. Tectonic setting of the Azores archipelago (simplified from Laughton and Whitmarsh 1974) and location of islands. $\mathrm{AM}=$ American plate; $\mathrm{EU}=$ Eurasian plate; $\mathrm{AF}=\mathrm{African}$ plate; $\mathrm{MAR}=\mathrm{Mid}$ Atlantic Rift; $----=$ Azores "leaky" transform; $\_$= Gloria fault zone; Islands: $\mathrm{C}=$ Corvo; $\mathrm{F}=$ Flores; $\mathrm{G}=$ Graciosa; $\mathrm{T}=$ Terceira; $\mathrm{SJ}=\mathrm{S}$. Jorge; FA = Faial; $\mathrm{P}=$ Pico; $\mathrm{SM}=\mathrm{S}$. Miguel; SMA = Santa Maria; FR = Formigas islets.

tried to date samples closely associated with those events. These are wood samples buried by pyroclastic deposits or charcoal found enclosed in lahars or in ignimbrites.

Paleosols interbedded within tephra layers were also sampled when they did not contain macroscopic bits of wood or charcoal. Most samples ( $c a .2 \mathrm{~kg}$ of material) were collected over the entire thickness of the paleosol $(5-20 \mathrm{~cm}$ ), but in three cases (FA1, FA3 and FA17), samples were collected from topsoil layers only (soil thickness $30-40 \mathrm{~cm}$ ). As the sampled paleosols are poorly developed, we think that a date from this kind of material is valid and is close to the age of the volcanic event that produced the deposit covering the dated horizon (see below for a more detailed discussion of this subject).

The single peat sample was collected from a very thin and discontinuous paleosol level $(5-10 \mathrm{~cm}$ thick) intercalated between two breccia deposits. This level contains carbonaceous clay clasts that were interpreted as fragments of a pre-existing soil, over which a thin layer of peat was developed. This means that the paleosol level is composed of two soils of different age, both of which were sampled (FA4-A1; FA4-A2) and dated.

Samples were first cleaned by manual removal of foreign material. Wood and charcoal samples and the peat sample were further decontaminated by acid/alkali/acid digestion. Soil samples were treated as follows to extract the humic acid fraction, which was used for the age determination: after wet sieving through a $250-\mu \mathrm{m}$ sieve to remove finer plant roots and/or animal organic remains, the soil sample was decalcinated using a $3 \% \mathrm{HCl}$ solution; humic constituents were extracted using a sodium hydroxide-sodium pyrophosphate solution $\left(0.1 \mathrm{M} \mathrm{NaOH}: 0.1 \mathrm{M} \mathrm{Na}_{4} \mathrm{P}_{2} \mathrm{O}_{7}\right)$, and the extract was acidified to $\mathrm{pH} 1.0$ with dilute $\mathrm{HCl}$ to recover the humic acid fraction. We measured ${ }^{14} \mathrm{C}$ content by liquid 
scintillation counting (Soares 1989). Stable isotope values $\left(\delta^{13} \mathrm{C}\right)$ were determined for the $\mathrm{CO}_{2}$ gas produced at the initial stage of benzene synthesis.

\section{RESULTS AND DISCUSSION}

Table 1 lists conventional ${ }^{14} \mathrm{C}$ ages for the samples collected from the stratigraphic sequence referred to above. As known, each annual tree ring "conserves" the particular ${ }^{14} \mathrm{C}$ content of the moment of the tree growth. The same can be said for each peat layer in a peat deposit. ${ }^{14} \mathrm{C}$ dating of wood, charcoal or peat in autochthonous position provides a close "true age" for the context with which the sample is associated. ${ }^{3}$ Most samples dated in this study conform to these conditions and, consequently, we were able to determine true ages for volcanic events that caused the burning and/or the burying of the plant specimens used. Soil samples from paleosols were also dated. The climate in the archipelago, characterized at present by warm and rainy conditions, favors vegetal growth and consequently pedogenic processes. During the Holocene, these conditions were also dominant. However, $\delta^{13} \mathrm{C}$ values of $\mathrm{NaOH}$ extracts (see Table 1) seem to indicate incipient pedogenesis, as the organic matter of the soil samples is not significantly ${ }^{13} \mathrm{C}$-depleted. On the other hand, when we tried to obtain a second alkali extract from paleosol samples, we obtained a small quantity, not enough to be dated, and the amount of organic carbon remaining in the residue, after the extractions, was always $<1 \%$ (and, in some instances, zero). All this seems to mean that either the pedogenesis was incipient because of the lack of time between volcanic episodes ${ }^{4}$ or because of the unfavorable morphological position of the deposit, or, being well developed, the upper horizon may have been eroded. If an erosion surface was not observed to truncate the paleosol, the date obtained, although it represents rigorously only a terminus post quem, must be close to the real age of the volcanic event that fossilized the sampled paleosol. With this background information, we can interpret the data in Table 1.

The oldest deposits of the Caldeira Formation are exposed near the southern, eastern and northern coasts of the island. In these areas, although the geological record is not complete due to erosion, at least three trachyte pumice fall episodes have been recognized. Closer to the caldera, younger pyroclastic products (two pumice falls associated with pyroclastic surges, pumice flows, volcanic breccias and phreatomagmatic deposits) cover the older deposits.

In those places where the three pumice events are preserved (Fig. 2A, profiles a and b), the oldest trachyte pyroclastic eruption is represented by pumice clasts contained in mudflow deposits. Unfortunately, the weak organic content of paleosols (FA12 and FA13) underlying these deposits has not allowed an age determination for this episode. At another locality, where only two of the older pumice fall deposits are present (Fig. 2A, profile c) the paleosol under the lower pumice was also sampled (FA3) and ${ }^{14} \mathrm{C}$-dated. The value obtained-10,250 $\pm 1770 \mathrm{BP}$-does not permit, because of the high standard deviation, correlation of this pumice deposit with the oldest or with the second deposit identified at Pasteleiro and Porto de Pedro Miguel. The lithologic characteristics of this tephra deposit at Galego also do not allow us to correlate it with one or other of the depcsits mentioned. Therefore, the age of the first event has not been determined yet. An age ca. 10 ka BP seems reason-

\footnotetext{
${ }^{3}$ Samples used in this study were collected away from main volcanic vents and known fumarolic sites. Thus, we assume that the dated biological material was not affected by ${ }^{14} \mathrm{C}$-depleted $\mathrm{CO}_{2}$ emissions.

${ }^{4}$ The submarine Capelinhos volcano (Capelo Complex) erupted in AD 1957-1958. Pyroclastic deposits from this eruption added new land to the island and covered its western part. Only 2 yr ago, some tiny patches of vegetation (mainly ferns) started to grow, but only at places where seabird excrement accumulated. Thus, it seems that the onset of soil formation is delayed for some tens of years after an eruption due to the low propagation rate of vegetation over fresh pyroclastic deposits.
} 


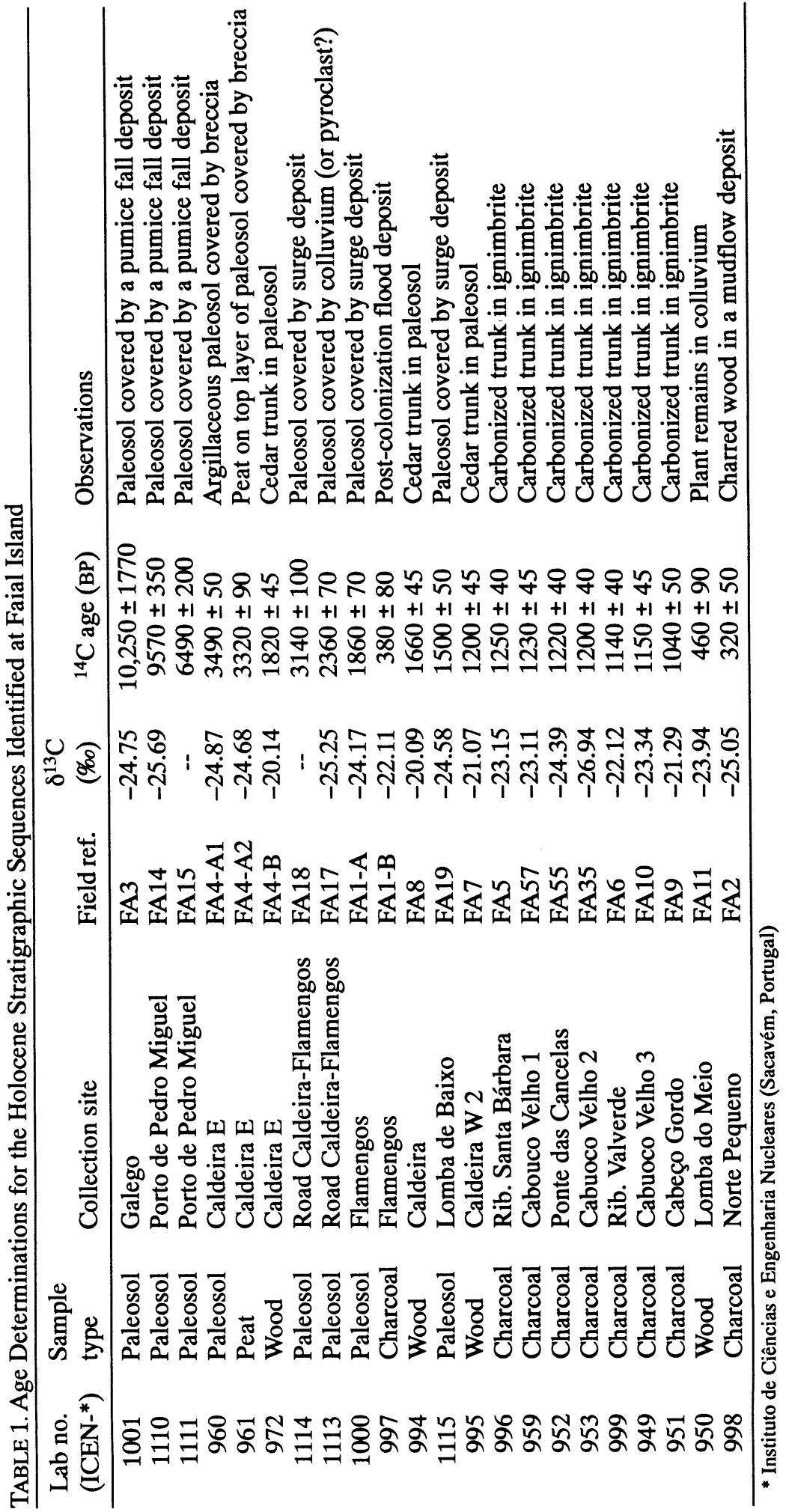


able and, consequently, the trachyte pyroclastic activity from the central stratovolcano of Faial (the Caldeira volcano) started at the beginning of the Holocene or a little before.

The second event is represented by a white (yellow when weathered) trachyte pumice fall deposit which, in places, overlies the mudflows containing fragments of the oldest pumice. At an exposure (Fig. 2A, profile b) where the three pumice events are preserved, one sample (FA14) from the paleosol fossilized by the second pumice gave an age of $9570 \pm 350 \mathrm{BP}$. A fall deposit, in which pumice grades upwards from white to gray, represents a third trachytic eruption. A sample (FA15) from the paleosol underlying this deposit yielded an age of $6490 \pm 200 \mathrm{BP}$.

A white trachyte pumice deposit, usually weathered to an orange-yellowish color, containing syenite lithic blocks not found in previous pumice falls, characterizes the fourth pumice event. As the base of this deposit is not exposed, and the deposit did not contain any organic material for dating, we can say only that its age is in the interval limited by the age of the third pumice deposit $(6940 \pm$ $200 \mathrm{BP}$ ) and the age, $3140 \pm 100 \mathrm{BP}$, of a paleosol (FA18) underlying a thin pyroclastic surge deposit identified in a roadcut between the Caldeira road and Lomba dos Flamengos (Fig. 2A, profile d). We believe that an explosion breccia older than $3940 \pm 50$ BP (FA4-A1), exposed near the caldera rim (Fig. 2A, profile f), may be a correlate of this pumice fall event.

The fifth pumice sequence includes several events associated with the deposition of at least five breccias, several phreatomagmatic pyroclasts, pumice flows and surges. Pumice fragments show a white and gray banding. Samples from paleosols underlying the first (second block in profile f, Fig. 2A) of these explosion breccias (a proximal facies) and a pyroclastic surge deposit (distal faciesFig. 2A, profile d) yielded equivalent ages, $3320 \pm 90 \mathrm{BP}$ (FA4-A2) and $3140 \pm 100 \mathrm{BP}$ (FA18), respectively, suggesting that both deposits represent the same eruption.

A second undated volcanic breccia rests directly on the breccia dated at $3320 \pm 90 \mathrm{BP}$ (Fig. 2A, profile f). A paleosol (FA17) underlying an alluvial (or perhaps pyroclastic?) deposit, exposed at the roadcut between the Caldeira road and Lomba dos Flamengos, was dated at $2360 \pm 70 \mathrm{BP}$, which may be equivalent to the undated breccia.

A third breccia (Fig. 2A, profile f) overlies soil that supported an abundant cedar and heather population. A wood sample (FA4-B) from this paleosol yielded a ${ }^{14} \mathrm{C}$ age of $1820 \pm 45 \mathrm{BP}$. At a distal position, intercalated in alluvial deposits, a phreatomagmatic pyroclast probably correlates with the third breccia; ${ }^{14} \mathrm{C}$ dating of the paleosol (FA1-A) underlying this pyroclast (Fig. 2A, profile $\mathrm{g}$ ) yielded an age of $1860 \pm 70 \mathrm{BP}$. A fourth volcanic breccia covers a paleosol supporting a rooted heather and cedar vegetation (Fig. $2 \mathrm{~A}$, profile $\mathrm{h}$ ). Some of the trees were $>100 \mathrm{yr}$ old when they fossilized (age determined by tree-ring counting), indicating a pause in volcanic activity for at least a century. A wood sample (FA8) provided an age of $1660 \pm 45$ BP.

A fifth volcanic breccia associated with phreatomagmatic pyroclasts (Fig. 2A, profile i) overlies a paleosol containing wood fragments (FA7) with a ${ }^{14} \mathrm{C}$ age of $1200 \pm 45 \mathrm{BP}$. This deposit is coeval to an important pumice flow deposit (ignimbrite) that covers most of the east and north flanks of the Caldeira volcano. The ignimbrite contains abundant charcoal fragments. Charcoal samples, collected at five locations (Fig. 2B, profiles j, k, l, m, n), yielded the following ages: $1250 \pm 40 \mathrm{BP}$ (FA5), $1230 \pm$ $45 \mathrm{BP}$ (FA57), $1220 \pm 45 \mathrm{BP}$ (FA55), $1200 \pm 40 \mathrm{BP}$ (FA35) and $1140 \pm 40 \mathrm{BP}$ (FA6). A pyroclastic flow deposit also containing charcoal (FA10) exposed in a trench opened at Cabouco Velho (Fig. 2B, profile o) provided a ${ }^{14} \mathrm{C}$ date of $1150 \pm 45 \mathrm{BP}$, and it is probably a product of the same ignimbrite eruption. Testing these seven dates for consistency, using the CALIB 3.0.3 calibration program (Stuiver and Reimer 1993), we conclude that they are statistically the same at the $95 \%$ level (test statistic $T^{\prime}=$ 


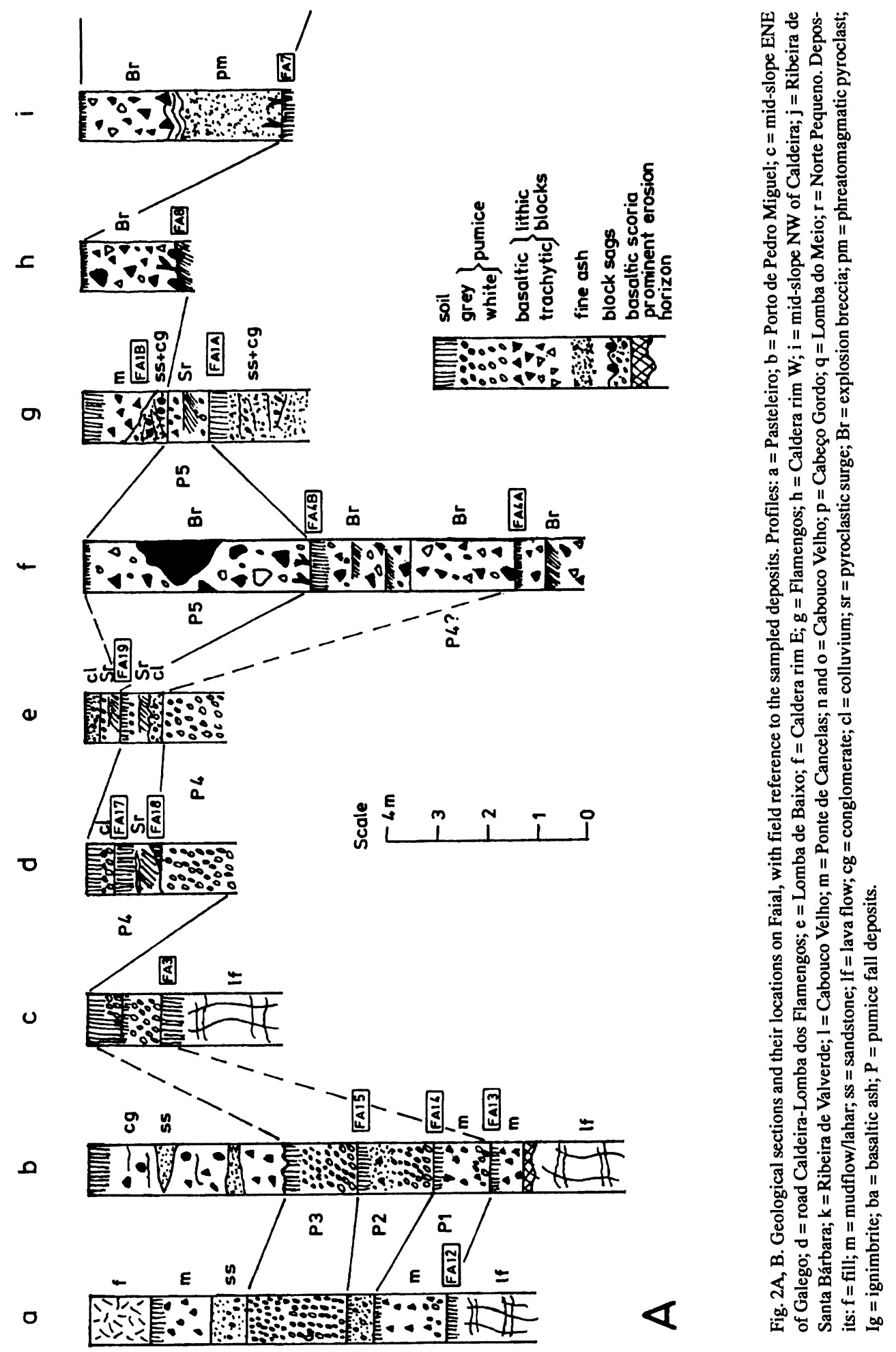




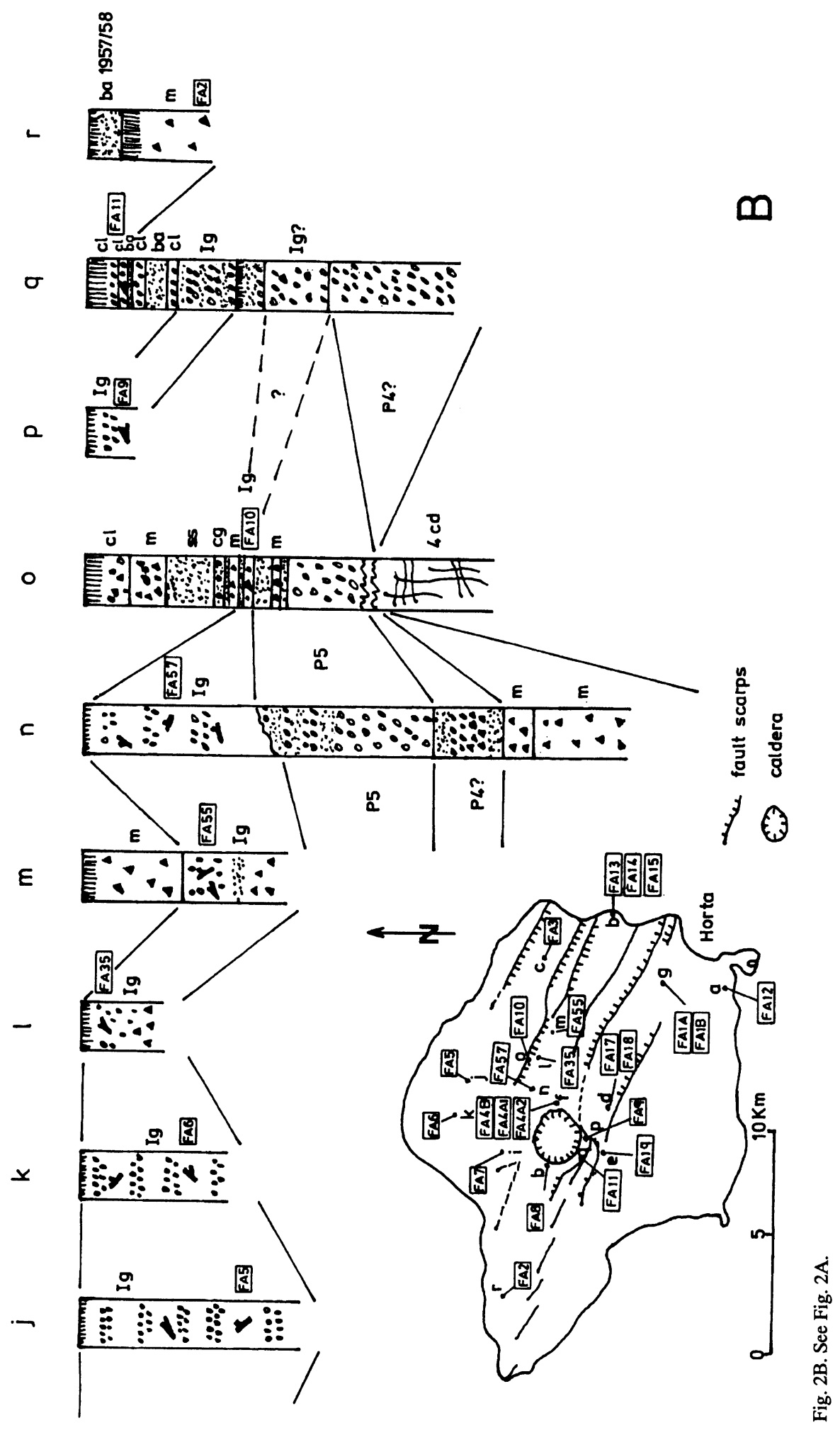


$\left.5.36 ; \chi^{2}(.05)=12.60\right)$ with a pooled mean value of $1199 \pm 17 \mathrm{BP}$. Another pyroclastic (surge) deposit exposed in a section at Lomba de Baixo (Fig. 2A, profile e) could also be of the same age. A paleosol sample (FA19) underlying that deposit was dated to $1500 \pm 50 \mathrm{BP}$. The difference between this value and the pooled mean age referred to above can be explained by the nature (a paleosol) of FA19, as discussed before. The younger pyroclastic deposit of the Caldeira Formation is a pyroclastic flow deposit exposed on the south flank of the volcano (Fig. 2B, profile p). Charcoal fragments (FA9) from this deposit provided an age of $1040 \pm 50 \mathrm{BP}$. The studied volcanic sequences and the obtained ${ }^{14} \mathrm{C}$ data allowed the establishment of a stratigraphic model for the Caldeira Formation (Fig. 3).

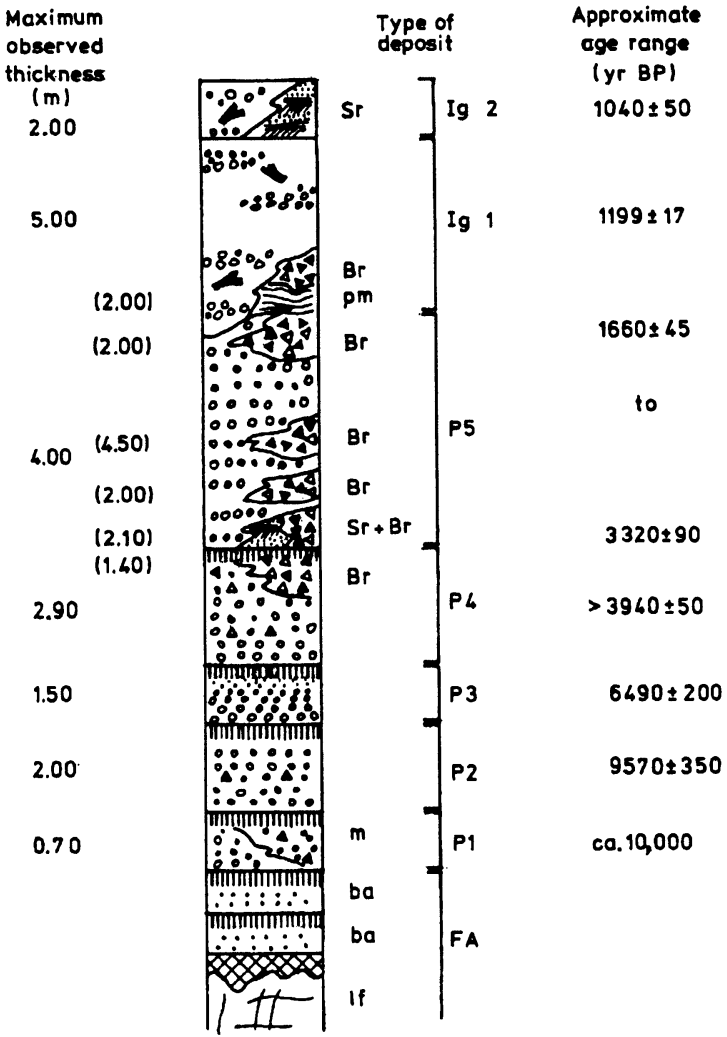

Fig. 3. Synthetic stratigraphic column of the Caldeira Formation volcanic products (not to scale; see Fig. 2 for key to symbols). FA = basaltic lava flows and ash layers of the Almoxarife Formation. Maximum observed thicknesses of lateral equivalents (breccias, phreatomagmatic and surge deposits) of pumice fall and ignimbrite deposits are in brackets.

Three other deposits unrelated to the Caldeira Formation were ${ }^{14} \mathrm{C}$ dated. The opening of a trench for paleoseismicity studies (Madeira, Brum da Silveira and Serralheiro 1994) exposed a colluvium related to a scarp-forming earthquake (Fig. 2B, profile q). This deposit (FA11), with an age probably prior to the settlement of the island ( $c a . \mathrm{AD} 1470$ ), gave a ${ }^{14} \mathrm{C}$ date of $460 \pm 90 \mathrm{BP}$, which, if calibrated using the Stuiver and Pearson (1993) curve, yields a date range of cal $\mathrm{AD} 1310$ to 1650 with a $95 \%$ probability.

A flood deposit of Ribeira dos Flamengos (Fig. 2A, profile g), containing bones and teeth of domestic animals, fragments of tiles, pottery and charcoal fragments, is obviously a "historic" (post-colonization) event. ${ }^{14} \mathrm{C}$ analysis of a charcoal sample (FA1-B) gave a date of $380 \pm 80 \mathrm{BP}$, and a date range, cal $\mathrm{AD} 1440$ to 1640 (with a 95\% probability), compatible with coeval written records describing floods in the Flamengos area, immediately after the first settlers moved to this locality. 
Finally, a mudflow deposit (Fig. 2B, profile r) containing abundant charcoal fragments at the base and pottery fragments at the top, underlying pyroclastic deposits from Capelinhos eruption (AD 1957-1958), was observed west of the village of Norte Pequeno. The assumption that it represents a mudflow induced by heavy rains that transported charcoal from fires started by lava flows during the 1672-1673 eruption of Cabeço do Fogo is not fully supported by radiocarbon analysis. A charcoal sample (FA2) yielded the date $320 \pm 50 \mathrm{BP}$ (cal AD 1450 to 1670 , with a $95 \%$ probability), slightly older than the expected age. Perhaps the charcoal dispersed in the sediments is of diverse origin, not only from fires started by the eruption.

\section{CONCLUSION}

One of the main geological formations - the Caldeira Formation-identified at Faial Island (Azores) was the subject of a tephrochronological investigation. Composite stratigraphic sections of pyroclastic deposits recording the sequence of eruptions of the Caldeira volcano were studied. ${ }^{14} \mathrm{C}$ dating provided a detailed time scale for tephra layers, permitting correlation among several sequences and, at the same time, allowing us to assess the frequency, importance and patterning of volcanic activity.

The ${ }^{14} \mathrm{C}$ data (19 dates) have provided ages for at least 10 explosive trachyte eruptions from the Caldeira stratovolcano that have occurred from $c a$. 10-1 ka BP. Correlations among deposits from the geologic sections have permitted the establishment of a stratigraphic model for the Caldeira Formation (see Fig. 3). We recognized five plinian events (pumices P1-P5) associated with pyroclastic flows and phreatomagmatic episodes. After $4 \mathrm{ka} \mathrm{BP}$, the data indicate that the activity of the Caldeira volcano occurred with smaller recurrence intervals between eruptions. We interpret this pattern to be the result of a more complete geological record compared to that relating to the older eruptions or, less probably, as a true increase in the frequency of eruptive activity. From 4-1 ka BP, at least seven eruptions occurred, separated by 800 - to 200 -yr intervals approximately (an average dormant interval of $400 \mathrm{yr}$ ), showing that the Caldeira volcano is an active and dangerous structure that needs close monitoring.

\section{ACKNOWLEDGMENTS}

We thank Prof. José Ávila Martins of Departamento de Oceanografia e Pescas da Universidade dos Açores, Dr. Manuel Fernando Vargas and Eng. Manuel Norberto Oliveira of Serviço de Desenvolvimento Agrário do Faial, Dr. Renato Leal Mayor of Câmara Municipal da Horta and Dr. Carlos Faria of Delegação do Ambiente do Faial for considerable logistical support during our fieldwork. This is a contribution from JNICT/DGFCUL Research Project PEAM/C/RNT/35/91 "Modelo sismotectónico de Portugal Continental e Açores".

\section{REFERENCES}

Laughton, A. S. and Whitmarsh, R. B. 1974 The AzoresGibraltar plate boundary. In Kristjansson, L., ed., Geodynamics of Iceland and the North Atlantic Area. Dordrecht, Reidel Publishing Co.: 63-81.

Madeira, J., Brum da Silveira, A. and Serralheiro, A. 1994 Paleoseismicity and neotectonics of the Lomba do Meio fault zone, Faial, Azores. Annales Geophysicae 12(1): 68 .

Serralheiro, A., Forjaz, V. H., Alves, C. A. M. and Rodrigues, B. 1989 Carta Vulcanológica dos Açores na Escala 1:15.000: Ilha do Faial. Centro de Vulcanologia do INIC/Serviço Regional de Protecção Civil dos Açores/Universidade dos Açores, eds., Ponta Delgada, 4 sheets.
Soares, A. M. M. 1989 OEfeito de Reservatório Oceânico nas Águas Costeiras de Portugal Continental. Sacavém, Instituto de Ciências e Engenharia Nucleares (Laboratório Nacional de Engenharia e Tecnologia Industrial): $135 \mathrm{p}$.

Stuiver, M. and Pearson, G. W. 1993 High-precision bidecadal calibration of the radiocarbon time scale, AD 1950-500 BC and 2500-6000 BC. In Stuiver, M., Long, A. and Kra, R. S., eds., Calibration 1993. $R a$ diocarbon 35(1): 1-23.

Stuiver, M. and Reimer, P. J. 1993 Extended ${ }^{14} \mathrm{C}$ database and revised CALIB $3.0{ }^{14} \mathrm{C}$ age calibration program. In Stuiver, M., Long, A. and Kra, R. S., eds., Calibration 1993. Radiocarbon 35(1): 215-230. 